in the New Agenda that the critical task is: continuing "collective conscientization," ongoing disruption of dominant exclusionary norms, and recreating the university's teaching and learning space and decision-making platforms. The discovery of Fanon may give some hope; his prescription for the road ahead is radically democratic: accept that the masses are thinking people. In the context of the university: accept that the African university will not arise from an aged, white, male professoriate, but from young, astute, black staff and students. They are thinking people; they do not want their universities to fall. Networked student power can potentially be engaged for all manner of radically democratic participation in decision-making, redesigning curricula, and reorganizing university life.

\section{Do or Die: The Dilemma of Higher Education in South Sudan}

\section{David Malual W. Kuany}

David Malual W. Kuany is dean, College of Education at Dr. John Garang Memorial University of Science and Technology, Jonglei State, South Sudan. He recently concluded the Mandela Washington Fellowship at Cambridge College, Massachusetts, and Florida International University, US. E-mail: malualwuor@yahoo.com.

W hen South Sudan became independent from Sudan in 20II, there were hopes that higher education, and education in general, would top the national spending priority list. However, the education sector lost emphasis when two ministries of higher education and general education were amalgamated to form one ministry, the current Ministry of Education, Science and Technology. Budgets were reduced as part of national austerity measures, staffs were redeployed, and directorates renamed. To make matters worse (to say the very least), when the country entered into what I personally call a war of insanity on December I5, 20I3, public universities were badly affected, with students, faculty and staff displaced, and assets destroyed. Now, at certain times, university administration is challenged with the question of whether to close universities or keep them open. This article analyzes the basic challenges facing higher education institutions in South Sudan, with the hope that the recent peace deal between government and rebels will be sustainable and provide tangible solutions.

\section{SNAPSHOt OF Higher Education}

South Sudan, the world newest nation, has a total of six universities. Five of these are public universities while one is a private institution. The top three university administrators are appointed by the president of the country. Each university has a vice-chancellor and two deputies for academic affairs and for administration and finance. Only one of the five university vice-chancellors is a woman. At the time of writing, the total number of students in all universities is estimated between 25,000 to 30,000 .

\section{Challenges}

The most important challenge to higher education in South Sudan is the vicious circle of insecurity in both the periphery and the center of the country. Four of the five public universities are located in states prone to be attacked either by the rebels fighting the government, or by local communities in conflict with each other. As a result, many highly skilled foreign academics have left the universities and returned to their countries, or sought jobs with international nongovernmental organizations. Because of insecurity and interruptions in the learning and academic cycles, many students left the country to get enrolled in neighboring countries such as Uganda, Kenya, Ethiopia, or Sudan. Some students and staff, traumatized by the murderous attacks, are too scared to return to the campuses and thus interrupt their studies or drop out of school altogether. However, the recent peace deal signed in Juba might help overcome this fear of insecurity.

\section{Brain Drain and Public Financing}

A number of outstanding, home-grown faculty have left South Sudan to seek refuge elsewhere, in search for greener pastures. Before July 2015, academics in South Sudan were receiving 35 percent less salary than their counterparts in East Africa. This led to brain drain. The incentive of state education is that beneficiaries should pay back to the state by way of serving the community in their respective specialties. This is compromised if these individuals prefer to work elsewhere. The implication is the insufficient number of faculty at public universities, hence the huge studentfaculty ratio.

The national government pays the salaries of staff and faculty at public universities, but little else. There is no funding available for construction or maintenance of infrastructure, for research, holding examinations, and student accommodations. With these realities, universities are faced with the challenge of having to shut down. So far, no university has done so, but extended holidays are not uncommon and severely disrupt academic life. The delays provoke frustration and exacerbate the need to improve 
working conditions.

\section{Technology and Labor Market Needs}

As in other developing countries, the demands of students enrolled nowadays in universities in South Sudan present a formidable challenge for university academics and administrators. Students need lecture theatres equipped with modern pedagogical equipment, air conditioning, stable electricity, and the means to commute to and from the university. Students are easily annoyed when lacking favorable conditions for learning. The faculty also face major challenges, lacking both standard equipment as well as knowledge on how to use digital resources.

The central purpose of education is to foster skills and values for individuals to successfully fit into society and engage in productive activity to earn a living. The current labor market requires a thorough understanding of modern technology, flexibility and creativity, and social intelligence. As observed above, insufficient technological tools might compromise the opportunity for university students to learn needed skills for the labor market, resulting in a mismatch of competencies and unemployment.

\section{The most important challenge to higher education in South Sudan is the vicious circle of insecurity in both the periphery and the center of the country.}

\section{Foreign Universities and Transnational Education}

The increasing number of private institutions of postsecondary education in neighboring Kenya, Uganda, Ethiopia, and Sudan reflects an enormous competition for students in the region. The attraction of South Sudanese to foreign universities is probably caused by better learning environments, course duration, curriculum, level of technology, higher standard of living at low cost, integrated student support mechanisms, and the diversity of the student population, which provides unique opportunities for international exchanges. These conditions prompt students to cross borders in search of better educational conditions. Students tend to leave for foreign universities where they are certain of graduating within a specified period of time, and with better standards as compared to domestic universities.

\section{CONCLUSION}

Although higher education in South Sudan faces enormous challenges, it is moving in the right direction. Since 20I3, more South Sudanese academics and staff have joined foreign universities for capacity building. If they return to the country, they will provide the much needed know-how to improve the quality of education. The recent peace deal, if it is sustained, will provide avenues for international interuniversity exchanges, improvement in learning facilities, an increase in student enrollment, especially women, and resources might be invested in education.

\section{Challenges to Doctoral Education in Africa}

Fareeda Khodabocus

Fareeda Khodabocus is director of quality assurance at the University of Mauritius and a member of the Higher Education Advocacy Network for Africa (HERANA). E-mail: f.khodabocus@uom.ac.mu.

R esearch is one of the three major pillars of higher eduRcation. For a university to progress and to address the needs and challenges of the knowledge industry, academics must constantly be engaged in research. For the past two decades, research universities across the United States, Europe, and developed countries at large have been placing increasing emphasis on the importance of doctoral education as an engine for growth of the knowledge economy. Along the same lines, researchers in Africa have undertaken various studies to investigate the process of universities functioning as tools for development for the African continent. Worldwide, new curricula and new jobs are emerging, replacing traditional ones. According to the US Bureau of Labor Statistics, jobs requiring a master's degree are projected to increase by 22 percent by the year 2020 , while positions requiring a doctoral or professional degree will increase by 20 percent. New areas and fields of research will thus emerge, calling for universities to innovate and adjust to the needs of society.

Eradication of poverty, access to education for all, empowering the younger generation with education, minimizing the brain drain, gender equity, and encouraging African women to participate in the development of Africa, have been high on African government agendas. To contribute to the realization of the Millennium Development Goals on the African continent, African universities are encouraged 